\author{
Barbora GONTKOVIČOVÁ ${ }^{1}$ \\ Emília DULOVÁ - SPIŠÁKOVÁ \\ Lucia BEDNÁROVÁ ${ }^{3}$
}

\title{
THE NON-FINANCIAL EMPLOYEE BENEFITS IN PRACTICE OF ENTERPRISES IN SLOVAKIA
}

Every company would like to have in his team the best, educated and clever people. However, educated person, who can assess their potential, expected in addition to adequate salary also various benefits. Therefore, it is not easy to hire him but also to maintain him. If the company appreciates its employees, offers them besides wage or salary also various non-financial benefits, which increase their loyalty and performance quality. Employee remuneration is an important function of personnel management from which uncoil other activities and relationships in the enterprise. Although each enterprise uses its own system of remuneration, it is always an important element of motivations and makes the company more attractive for potential job applicants. Nowadays, every company should be interested in actual state and news in remuneration and thereby enhances its competitiveness in the market and improves the company image. The aim of this paper is to bring about comprehensive look at the issue of employee benefits with separate attention to non-financial benefits as well as analyze and compare the system of non-financial benefits used in the enterprises in Slovakia. In addition, we observe the distribution of non-financial benefits given the ownership of enterprises. The analysis is done on the basis of the secondary data from the salary survey. Employee remuneration should support the achievement of strategic and short-term objectives by helping to ensure skilled and motivated workforce that enterprise needs and is needed paid adequate attention to this issue.

Keywords: strategy, remuneration, benefits, motivation, employees.

\section{INTRODUCTION}

The employee remuneration is no longer just about monthly payment of wages and salaries. More and more emphasis is now placed on employee benefits by means of them the enterprises motivate employees to higher performance and trying to retain quality employees. Remuneration can motivate employees to be more productive but does not have to be necessarily based on finance.

\footnotetext{
1 Ing. Barbora Gontkovičová, PhD. , University of Economics in Bratislava, Faculty of Business Economics with seat in Košice, Tajovského 13, 04130 Košice, Slovakia, mail: barbora.gontkovicova@euke.sk

${ }^{2}$ Ing. Emília Dul'ová Spišáková, PhD., University of Economics in Bratislava, Faculty of Business Economics with seat in Košice, Tajovského 13, 04130 Košice, Slovakia, mail: emilia.spisakova@euke.sk

${ }^{3}$ doc. Ing. Lucia Bednárová, PhD., University of Economics in Bratislava, Faculty of Business Economics with seat in Košice, Tajovského 13, $041 \quad 30$ Košice, Slovakia, mail: lucia.bednarova@euke.sk
} 
The effective reward strategy defines longer-term intentions in such areas as pay structures, contingent pay, employee benefits, steps to increase engagement and commitment and adopting a total reward approach ${ }^{4}$. The remuneration of employees is complicated and often not entirely clear matter to which is focused attention of both employees and also their employers. For this reason, it is a personnel action, which often causes controversy. One of the most important motivating factors that create harmonious relationships in business is mutually acceptable and effective system of remuneration ${ }^{5}$.

Every company has a different system of remuneration, but compensation and benefits always belong to the most important factors affecting employee motivation. Also, employees have different preferences. Some prefer cash, others for example experience in the form of free tickets to the theatre. The benefits must be distinguished from the compensation. Compensation means the right claimed reimbursement of employee services by the employer. By contrast, benefits are financial or non-financial services that employer provides to employees to improve the lives and to increase the motivation, loyalty, quality and quantity of their performance. According to Armstrong ${ }^{6}$, employee benefits include pensions, sick pay, insurance cover, company cars and a number of other 'perks'. They consist of elements of remuneration additional to the various forms of cash pay and also include provisions for employees that are not strictly remuneration, such as annual holidays.

\section{FINANCIAL AND NON-FINANCIAL BENEFITS}

Generally, employers use a combination of financial and non-financial benefits. The financial reward has usually short-term effect and it's reward for a specific task, filled with purpose. Non-financial benefits strengthen the loyalty and involvement. Form and manner of offering benefits are in many companies linked to the corporate culture and values of employees. Definitely, most motivates mutually balanced system that can meet the needs of the employee. Well-chosen benefits make a suitable balance between work and leisure (spa, theatre tickets, etc.) for employees. These are for someone very important and in choosing a job take account of it. Conversely, other employees do not use any of the offered benefits and is essential for them what "money" receive for their work. The employer has to well know of their people and their priorities for well setting the remuneration package ${ }^{7}$. The fact is that up to $56 \%$ of employees in Western Europe and 44\% of employees in Eastern Europe said their organizations did not support them in achieving a reasonable work-life balance ${ }^{8}$. Also of interest is the observation that about $44 \%$ employees across all management cadres

\footnotetext{
${ }^{4}$ M. Armstrong. A Handbook of Employee Reward Management and Practice. Kogan Page Publishers, 2007.

${ }^{5}$ B. Dugasová, A. Tkáčová. Benefits for employees. [in:] POSTER 2012: 16th International Student Conferenece on Electrical Engineering. Praha: Czech Technical University in Prague, 2012.

${ }^{6}$ M. Armstrong. A Handbook of Employee Reward Management and Practice. Kogan Page Publishers, 2007.

${ }^{7}$ B. Dugasová, A. Tkáčová. Benefits for employees. [in:] POSTER 2012: 16th International Student Conferenece on Electrical Engineering. Praha: Czech Technical University in Prague, 2012.

${ }^{8}$ Hay Group. Developing a Work-Life Culture of Balance, 2013
} 
are either unsure or think the employer does not provide accurate, helpful information about employment benefits 9 .

Benefits are programs which an employer uses to supplement the cash compensation that employees receive. These programs are designed to protect the employee and his or her family from financial risks. Some benefits are provided across the board (for all employees), others may be provided for example in relation to the employee function in the company, length of employment, the status of a worker in a company or to its merits ${ }^{10}$.

The financial reward may be eligible (guaranteed in the contract) or voluntary (derived of the size of the company's profits). The first group consists mainly of so-called payment of the thirteenth or fourteenth salary. The second group of these benefits is usually paid in quarterly, half yearly or annual basis and depends on the economic profit for the previous financial year. The remuneration shall be paid as a certain percentage of net profit.

At the present, more and more companies provide to their employees non-financial benefits. Their range is different - from providing drinks to the workplace through flexible working hours, provision of official telephones and cars for private purposes after payment of above-standard care ${ }^{11}$. For example NIKE, Inc.'s competitive benefits program provides to employees with the opportunity to stay fit, ensure the wellness of their families, and create a positive working environment. Hence, company provides variable health coverage, fitness centre memberships, time off, retirement savings, and more $^{12}$.

The main benefits deal with personal security, financial assistance, personal needs, company cars and voluntary benefits ${ }^{13}$ :

- Personal security (Health care, Insurance cover, Sick pay, Redundancy pay, Career counselling);

- $\quad$ Financial assistance (e.g. Company loans, Mortgage assistance);

- Personal needs (e.g. maternity and paternity leave and pay above the statutory minimum; childcare through workplace nurseries or vouchers; sports and social facilities);

- $\quad$ Additional days of holiday;

- Mobile phone, Laptop and company car for private purposes;

- Other benefits, such as free car parking, Christmas parties and tea/coffee/cold drinks;

- Voluntary ('affinity’) benefits (provide opportunities for employees to buy goods or services at discounted prices. The employer negotiates deals with the providers but the scheme does not cost the employer anything, e.g.: travel insurance, gym membership.);

- Concierge services.

\footnotetext{
${ }^{9}$ Ernst \& Young LLP. EY Rewards Survey 2016, 2016.

${ }^{10}$ J. Dědina, V. Cejthamr.. Management a organizační chování. Praha, Grada Publishing, 2005.

${ }^{11}$ B. Dugasová, A. Tkáčová. Benefits for employees. [in:] POSTER 2012: 16th International Student Conferenece on Electrical Engineering. Praha: Czech Technical University in Prague, 2012.

${ }^{12}$ Nike. Benefits, 2014.

${ }^{13}$ M. Armstrong. A Handbook of Employee Reward Management and Practice. Kogan Page Publishers, 2007.
} 
An employee without benefits will easily leave your company to work for another that offers a benefits package. When employees have a job that offers great benefits, they are less likely to leave that job. Many enterprises (employers) associate the benefits with high costs. However, if company loses an employee, loses also money. When an employee leaves, it means for company incurred expense for replacing. For example, cost related with advertising of the vacant job position, training for the new employee which not yet produces. Consequently, it's more economical to give benefits to employees than to have cost with training new ones.

Currently, there are many low-cost ways to reward employees. According to Forbes magazine, research shows that feeling appreciated - which comes from recognition from others -is one of the top three drivers of employee engagement. Among low-cost employee appreciation ways may be included, for example a sincere word of thanks (costs nothing and is very effective), honour the employee at the start of the next staff meeting (recognize someone at the start of every staff meeting), give to employee a card with lottery/movie tickets inside or let them dress casual for a day ${ }^{14}$.

Regardless of country, benefits supplement compensation by providing employees with a level of security related specifically to health and welfare, retirement and time off. However, popularity of specific employee benefits varies from country to country. Currently, services with non-working character (such as cleaning, mowing the lawn) become strong in developed countries. The offer of benefits is so large that benefits are often the main attraction to draw the professionals and valued employees. The health insurance payment by the employer, which was not at all commonplace until recently, is a major benefit in USA. It is a prestigious benefit which often covers the entire family of the employee. But most companies in European countries don't offer this employee benefit, because it is provided through government-sponsored socialized medicine programs. Diversity of benefits is also observed in the developed countries of Western Europe. Most employees appreciate the benefits oriented at stability and the future of family background (in particular, pension contributions, life insurance and health care). This trend manifests itself slowly towards the east, but by far not as much. The tangible benefits still outweigh compared with future reinsurance in Central and Eastern Europe ${ }^{15} .95 \%$ of companies in Western countries attract employees on the added value that the employees do not see immediately, but the benefit financially secure him in unexpected life situations. Companies pay life insurance to employees. In Slovakia, the notebook is considered as benefit, but it should be considered as working tool and not employee benefit ${ }^{16}$.

In addition to geographical differences, there are some gender differences in the perception of benefits. As much as $66 \%$ women cited satisfaction with their pay as compared to $50 \%$ men - this probably indicates that while men focus on the cash components of the rewards program, women tend to view it as a complete package, wherein benefits are assigned more values than any other reward components ${ }^{17}$. Also, different generations prefer different benefits and that the same employees prefer different benefits at different life stages. And we cannot forget the fact that some

\footnotetext{
${ }^{14}$ K. Kruse. 25 Low-Cost Ways to Reward Employees, 2013.

${ }^{15}$ PracovnePonuky.sk. Oblúbené a zaujímavé zamestnanecké benefity v SR i zahraničí, 2012.

${ }^{16}$ TASR. Najrozšírenejšimi benefitmi firiem sú stravné listky, notebook a mobil, 2016.

${ }^{17}$ Ernst \& Young LLP. EY Rewards Survey 2016, 2016.
} 
benefits are close related with economy sector. For example, benefit such as flexible working hours is absurd for assembly-line worker.

\section{EMPLOYEE BENEFITS TRENDS IN SLOVAKIA}

Benefits help to increase the competitiveness of companies, easier to get employees to market and build employee pride in the company. They have an indirect impact on employee performance management, help to stabilize.

Profesia, spol. s.r.o. is the author of the salary survey, which has carried out in Slovakia since 2007. On its website Platy.sk you can get salary comparison for about 500 job positions. List of the positions reflects the labour market in Slovakia and is continually updated. Currently, the questionnaire survey has nearly 80,000 respondents and it is the biggest salary database in Slovakia. All data for our analysis was provided by Profesia, spol. s.r.o..

As one might expect easily, the most desirable benefit in Slovakia are financial compensations ${ }^{18}$. While the popularity of financial benefits applies in particular to manufacturing enterprises, employees in other sectors have begun to prefer non-financial rewards. The benefit policies in companies are usually stable, thus these items do not change too much from year to year. The majority of changes apply to benefits that are regulated externally or are required by a new generation of employees. The benefits linked to the corporate culture are different in different sectors. In the banking business, it is options for corporate shares. In IT, employers usually provide a variety of technological toys for business and special trainings, in the automotive industry there are discounts for buying cars made by the brand ${ }^{19}$.

On Figure 1 we can see changes in providing non-financial benefits by comparison 2010 and 2016.

Education (23\%), flexible working hours (21\%) and free drinks at workplace $(20 \%)$ were the most used benefits in 2010. Currently, corporate events are the most commonly providing benefits $(28 \%)$. Also, free drinks $(22 \%)$, flexible working hours $(20 \%)$ and education $(20 \%)$ belong among frequented employee benefits.

The employee benefits such as extra health insurance or above-standard medical care are rather rare in Slovakia. It is related with the state funded healthcare system and fact that the healthcare contributions are mandatory. Each employed citizen has to pay contributions to the health insurance company.

\footnotetext{
${ }^{18}$ Platy.sk. L'udia by namiesto benefitov chceli vidiet' viac peñazi na výplatnej páske, 2013.

${ }^{19}$ P. Adamovský. Employee benefit packages evolving, 2015.
} 
Figure 1, Employee non-financial benefits in Slovakia (2010, 2016)

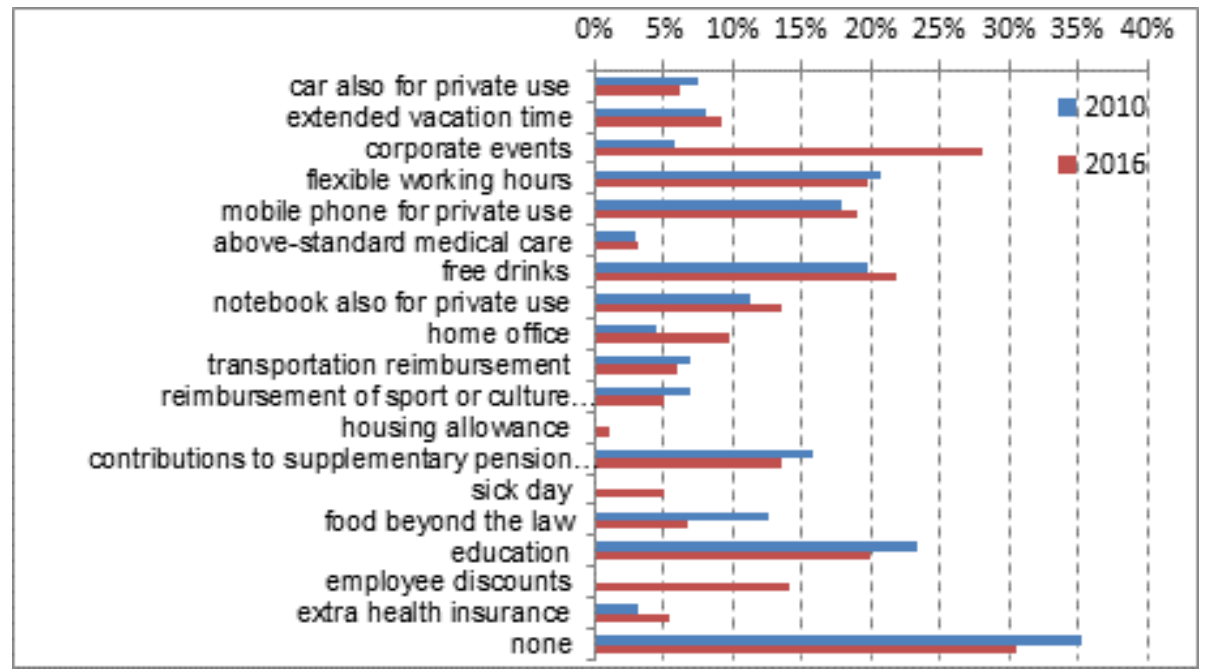

Source: Own processing according data from Profesia

However, $35 \%$ of respondents adduce that they had not any non-financial benefit in 2010. In 2016 it is $30 \%$. In spite of decrease, there is a place for improvement and we expect that non-financial benefits will be common element of reward strategy for absolute majority of enterprises in Slovakia in the future.

\subsection{Employee Benefits Differences according to enterprise ownership}

It is often said, that the trend of employee benefits comes to Slovakia from foreign companies. Through Figure 2 we can identify the differences between providing non-financial benefits according to enterprises ownership.

We see a number of differences. Whereas in $2010,40 \%$ of employees in domestic companies and $24 \%$ in foreign companies had not any non-financial benefit, we observe the positive change in form of decrease of value in $33 \%(-7 \%)$ in case of private domestic companies and 19\% (-5\%) in foreign companies in 2016. As for state and municipal company, the increase from $30 \%$ (in 2010) to $34 \%$ (in 2016) means downgrade in field of benefits providing.

Employee benefits such as free drinks (21\% in 2010, 26\% in 2016), mobile phone for private use (19\% in 2010, 23\% in 2016), flexible working hours (19\%) are standard the most used in the domestic companies. In addition, we observe the considerable increase $(+20 \%)$ of corporate events in private domestic companies in 2016. It can be a result of influence of foreign companies, because corporate events are their most used employee benefit with share of $42 \%$ in 2016. Furthermore, free drinks (28\%), education (35\% in $2010,28 \%$ in 2016) and flexible working hours $(26 \%$ in $2010,27 \%$ in 2016) belong among frequented employee benefits in foreign companies. We can see that private domestic and foreign companies the most use the same types of non-financial benefits. 
On the other hand, contributions to supplementary pension savings (30\% in 2010, $27 \%$ in 2016) and extended vacation time (23\% in $2010,26 \%$ in 2016) are most provided employee benefits in state and municipal enterprises. Nowadays, more and more employers aware that the basis for the success in any kind of business is professionally competent staff, which in turn requires high-quality training and education ${ }^{20}$. That's just it is interesting a significant decrease of education $(-13 \%)$. On this basis, it can be concluded that the state and municipal enterprises should focus more attention and funding for employee development.

Figure 2, Comparison of employee non-financial benefits according to enterprise ownership

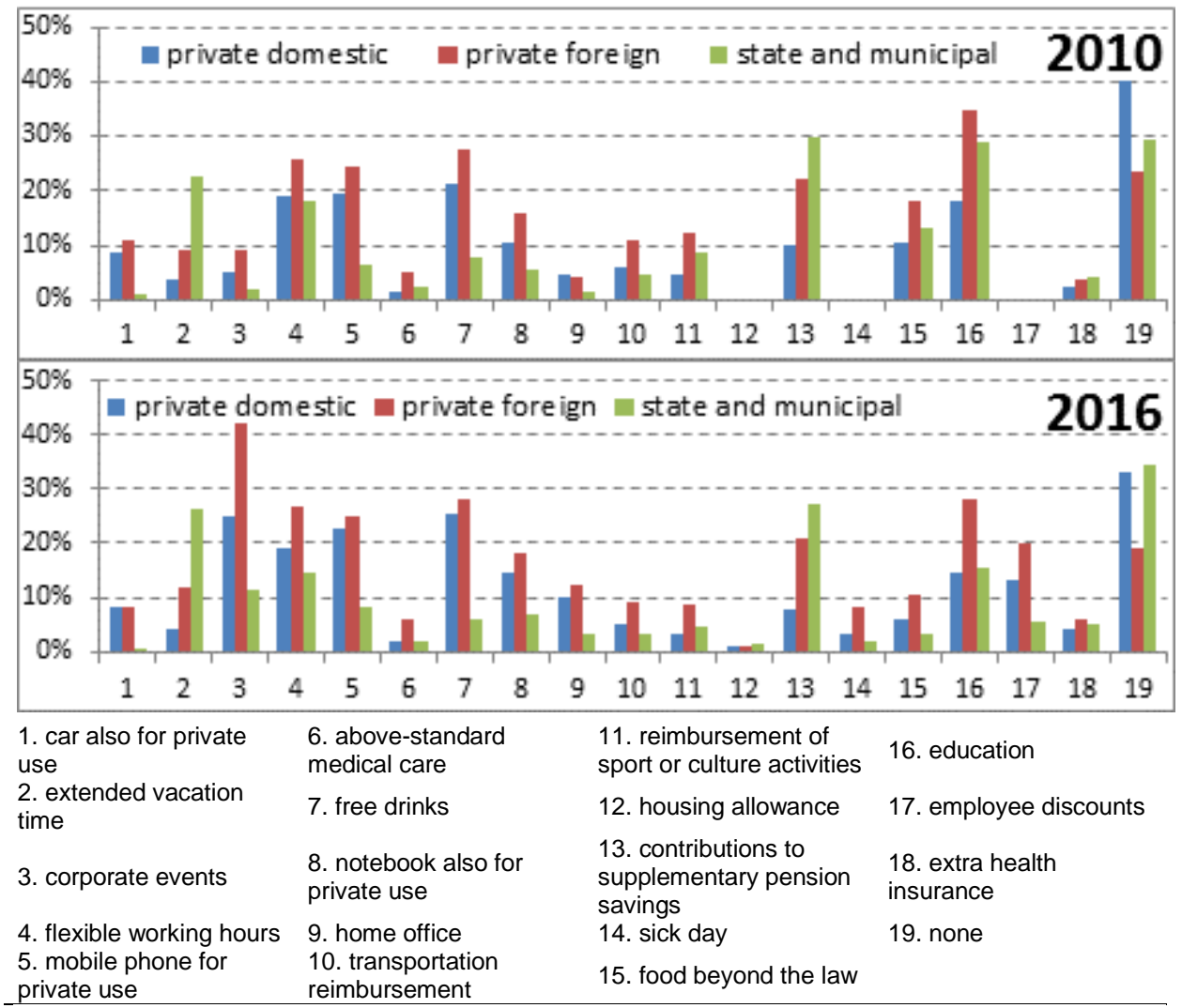

Source: Own processing according data from Profesia

Figure 3 provides information about the variability of values in data set through boxplot. In its simplest form, the boxplot presents five sample statistics -

\footnotetext{
${ }^{20}$ B. Gontkovičová, E. Dul’ová Spišáková. The Necessity of employee education. [in:] Modern management review, 2015.
} 
the minimum, the lower quartile, the median, the upper quartile and the maximum in a visual display. As we see, all samples are skewed to the right. There are no obvious outliers in any of the samples.

However, obvious differences are immediately apparent. Box plot for private foreign enterprises (mainly in 2016) is much higher than two others. This suggests a difference between groups. Sample of private foreign enterprises have larger variability than the other two samples. The smallest change in time is recorded for domestic private enterprises. Whereas employees in 2010 a half of observed non-financial benefits were provided to $4.5-14.4 \%$ of employees, in 2016 interquartile range is $4.1-14.5 \%$. In case of state and municipal enterprises, the value of median is the smallest. This means the lowest rate of providing employee benefits. Only about $3-11 \%$ of employees received half of observed non-financial benefits.

Figure 3, Boxplot of employee non-financial benefits according to enterprise ownership
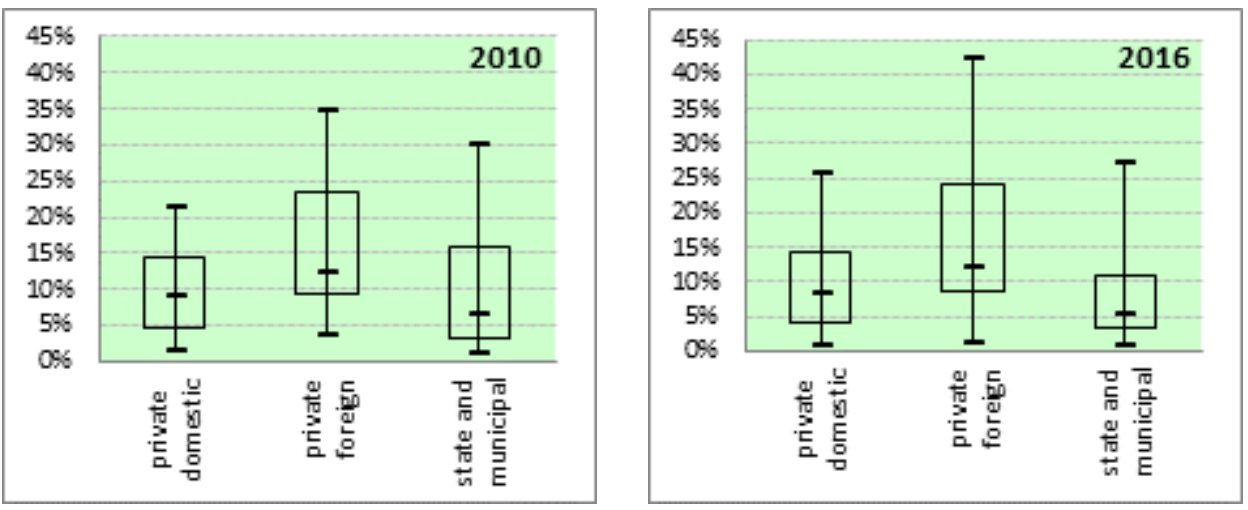

Source: Own processing according data from Profesia

In general, we see a positive trend in providing benefits. The share of employees receiving non-financial benefits increases. Corporate events achieve the biggest change - increase of $22 \%$. In 2016, new forms of benefits started to use, namely housing allowance, sick day and various employee discounts. From the comparison, we can see that foreign companies on the Slovak market use the non-financial benefits more than domestic and state or municipal enterprises. This situation is very often in post communism countries where more frequented were financial benefits. The trend of non-financial benefits came to these countries with entry of foreign companies from Germany, France, Italy and Japanese on the market forasmuch as these enterprises have a big size and have enough finance for providing non-financial benefits for employees.

\section{CONCLUSION}

Employee benefits are a significant element of motivation. Reward depends on employee performance evaluations and it is also start point to improvements or remaining in the workplace. Nowadays, non-financial benefits acquire their place 
in the system of remuneration and their importance is increasing. On the basis of the results of analysis we can state, that approximately $70 \%$ of employees receive some non-financial benefit in Slovakia. Generally, the most popular are corporate events, free drinks, flexible working hours and education. Private domestic and foreign companies use lots of same types of non-financial benefits. When comparing private and public companies, there are differences not only in volume but also in their composition. The most provided employee benefits in state and municipal enterprises are contributions to supplementary pension savings and extended vacation time, but there has been a decline in the providing non-financial benefits compared to the 2010 .

This article was supported by the Scientific Grant Agency of the Ministry of Education, Science, Research and Sport of the Slovak Republic as part of the research project VEGA 1/0708/14.

\section{REFERENCES}

[1] Adamovský, P. Employee benefit packages evolving, 2015, http://spectator.sme.sk/c/20057383/employee-benefit-packages-evolving.html (last viewed 10.08.2016).

[2] Armstrong, M. A Handbook of Employee Reward Management and Practice. Kogan Page Publishers, 2007.

[3] Dědina, J., Cejthamr, V. Management a organizační chování. Praha, Grada Publishing, 2005. $339 \mathrm{~s}$.

[4] Dugasová, B., Tkáčová, A. Benefits for employees. [in:] POSTER 2012: 16th International Student Conferenece on Electrical Engineering. Praha: Czech Technical University in Prague, 2012 P. 1-5. ISBN 978-80-01-05043-9.

[5] Ernst \& Young LLP. EY Rewards Survey 2016, 2016, http://www.ey.com/Publication/vwLUAssets/EY-total-rewardssurvey/\$FILE/EY-total-rewards-survey.PDF (last viewed 16.08.2016).

[6] Gontkovičová, B., Dul'ová Spišáková, E. The Necessity of employee education. [in:] Modern management review. 2015, vol. 20, no. 1, pp. 131141.

[7] Hay Group. Developing a Work-Life Culture of Balance, 2013, http://www.haygroup.com/downloads/ar/White_Paper_Work_lifeBalance.pdf (last viewed 16.08.2016).

[8] Kruse, K. 25 Low-Cost Ways to Reward Employees. 2013, http://www.forbes.com/sites/kevinkruse/2013/03/01/25-low-cost-ways-toreward-employees/\#388b44ea2233 (last viewed 26.08.2016).

[9] Nike. Benefits. 2014, http://jobs.nike.com/article/benefits (last viewed 16.08.2016).

[10] Platy.sk. L'udia by namiesto benefitov chceli vidiet' viac peňazí na výplatnej páske, 2013, http://www.platy.sk/analyzy/ludia-by-namiesto-benefitovchceli-vidiet-viac-penazi-na-vyplatnej-paske/50116 (last viewed 23.08.2016).

[11] PracovnePonuky.sk. Oblúbené a zaujímavé zamestnanecké benefity $v$ SR $i$ zahraniči, 2012, http://pracovneponuky.sk/clanky/hladam-pracu/oblubene-azaujimave-zamestnanecke-benefity-v-sr-i-zahranici (last viewed 24.08.2016). 
[12] TASR. Najrozširenejšími benefitmi firiem sú stravné lístky, notebook a mobil. 2016, https://www.istp.sk/clanok/10513/Najrozsirenejsimi-benefitmi-firiemsu-stravne-listky-notebook-a-mobil (last viewed 25.08.2016).

\section{NIEFINANSOWE ŚWIADCZENIA PRACOWNICZE NA PRZYKŁADZIE}

\section{PRZEDSIEBIORSTW NA SLOWACJI}

Każda firma chciałaby mieć w swojej drużynie najlepszy, wykształconych i mądrych ludzi. Jednakże, wykształcony człowiek, który może ocenić potencjał firmy, oprócz odpowiedniego wynagrodzenia oczekuje również innych korzyści. Dlatego też, nie jest łatwo go zatrudnić, a co więcej zatrzymać go. Jeśli firma docenia swoich pracowników, poza wynagrodzeniem oferuje również dodatkowe korzyści niefinansowe, które zwiększają lojalność pracowników oraz jakość ich pracy. Wynagrodzenie pracowników jest ważnym czynnikiem zarządzania personelem. Chociaż każde przedsiębiorstwo korzysta $\mathrm{z}$ własnego systemu wynagrodzeń, to jest on zawsze ważnym elementem motywacji i sprawia, że firmy stają się bardziej atrakcyjne dla potencjalnych kandydatów do pracy. W dzisiejszych czasach każda firma powinna być zainteresowana rożnymi formami wynagrodzeń, co zwiększa jej konkurencyjność na rynku i poprawia wizerunek firmy. Celem niniejszego artykułu jest wprowadzenie kompleksowego spojrzenia na kwestię świadczeń pracowniczych ze szczególnym uwzględnieniem świadczeń niefinansowych stosowanych $\mathrm{w}$ przedsiębiorstwach na Słowacji. Analizy dokonano na podstawie danych wtórnych dotyczących wynagrodzeń. Wynagrodzenie pracownika powinno wspierać realizację celów strategicznych i krótkoterminowych, przyczyniając się do zatrudniania wykwalifikowanych i zmotywowanych pracowników.

Slowa kluczowe: strategia, wynagrodzenia, świadczenia, motywacja pracowników.

DOI:10.7862/rz.2016.hss.41

Przesłano do redakcji: styczeń 2016

Przyjęto do druku: wrzesień 2016 